Љиљана М. БАЬАНИН*

Dipartimento di Lingue e Letterature straniere e Culture moderne, Torino
Оригинални научни рад

Примљен: 27. 1.2021.

Прихваћен: 25. 2. 2021.

\title{
ОД СУМАТРЕ ДО ДНЕВНИКА О ЧАРНОЈЕВИЋУ: ЦРЬАНСКИ НА ИТАЛИЈАНСКОМ
}

\begin{abstract}
Полазиште у реферату су преводи поетских и прозних дела Милоша Црњанског на италијански. Циљ је да се укаже да проблеме везане за поетско и књижевно превођење уопште, као и на улогу преводиоца од чијег професионалног профила и преводилачке агилности у највећој мери зависи резултат (добар/лош превод) а самим тим и рецепција књижевног дела.

Кључне речи: српска књижевност, Милош Црњански, преводи, италијански језик.
\end{abstract}

Преводи као најдиректнији канал који омогућава циркулацију књижевних дела у иностраној средини захвалан су материјал како за праћење рецепције једног дела, аутора и књижевности, тако и за анализу превода према оригиналу.

Док је свако књижевно дело јединствено и непоновљиво, превод је његов варијабилни рефлекс, скуп многих литерарних али и ванлитерарних момената, резултат опште и културне климе рецептора/примаоца од које зависи одабир дела и аутора, али улогу у овом процесу има и преводилац, његово читање, интерпретација, преводилачке стратегије, те лични и колективни сензибилитет средине примаоца. Милош Црњански и његово дело могу да послуже као захвалан материјал за истраживање свих ових аспеката. У једном нашем претходном раду фокус је био на представљању Црњанског у италијанској научно-популарној литератури, у славистичким и неславистичким публикацијама (Бањанин 2004: 509-520), а бавили смо се такође и детаљном анализом превода Суматре на италијански језик (Бањанин 2014). Овај рад заокружава та бављења, допуњује их новим подацима и информацијама о преводима, као и о „фортуни” Црњанског у Италији у другој половини 20. века и у новом миленијуму, са циљем да се укаже на разлоге због којих долази до осцилирања у рецепцији књижевног опуса овог нашег писца и на проблеме везане за превођење на италијански. Тиме ћемо се дотаћи и

*1jiljana.banjanin@unito.it 
профила преводилаца од чије улоге зависи резултат (добар/лош превод) а у крајњој линији и рецепција књижевног дела.

Мада се не ради о преводу из богатог опуса Црњанског, вредан је пажње хронолошки први помен путописа Љубав у Тоскани, који датира из 1930. г. Тада се у престижном славистичком часопису „Rivista di Letterature slave”, чији је уредник био један од оснивача италијанске славистике Еторе Ло Гато (Ettore Lo Gatto), Умберто Урбани (Umberto Urbani, 1888-1967) огласио полемичким текстом као одговором непознатом словеначком рецензенту у љубљанском „Slovenec”, који је критиковао путопис Љубав у Тоскани и његовог аутора. У вероватно сопственом преводу појединих кратких цитата Урбани поткрепљује тврње да се ради о „химни” у славу Италије једног врсног познаваоца италијанске културе, уметности и књижевности. Урбани на овај начин потврђује да је и сам помно пратио најновија књижевна догађања у српској књижевности, ако се има у виду да је путопис на српском објављен те исте године, али и да је осетио и препознао његову изузетност као авангардног текста. Сем тога, његов чланак сведочи и о индиректним путевима којима су италијански читаоци били информисани о књижевним новитетима, као и о одјеку који је Љубав у Тоскани имао на тадашњој југословенској књижевној сцени.

У деценији која следи у краћим или дужим временским размацима, излазили су преводи пре свега Суматре што сведочи о томе да је била преводилачки изазов. Оно што је заједничка карактеристика готово свих њих јесте да су издања престижна: ради се о антологијама југословенске, српско-хрватске и српске поезије и књижевности. При томе треба подвући и нијансу у наслову тих антологија јер одражава тренутно стање у књижевном па и шире, политичком контексту у односима између две културе, а када се ради о примаоцу, одраз је и оријентисаности уредника едиције или приређивача антологије према суседима.

Потписник првог превода Суматре у збирци Чедне виле. Југословенско песништво (Le Candide Vile. Poesie Jugoslave, [1941]) је Луиђи Салвини (Luigi Salvini, 1911-1957), врстан лингвиста, слависта и преводилац са словенских језика. Зналачки одабраним насловом који асоцира на народну поезију у овој антологији од свега 350 нумерисаних и раритетних примерака, он је понудио италијанским читаоцима стихове двадесетак словеначких, хрватских и српских песника, међу њима и Црњанског, без пропратних медаљона или објашњења. После ове антологије тек 1959. г. у Падови Освалд Рамоус (Osvaldo Ramous, 1905-1981) песник, писац, музички и позоришни критичар и аниматор културног живота италијанске националне мањине у Ријеци ${ }^{1}$ приредио је своју антологију у чијем је наслову акценат на југословенском песништву, као и код Салвинија. У предговору Савременог југословенског песништва (Poesia jugoslava contemporanea) приређивач и преводилац наводи као један од разлога свог издавачког подухвата чињеницу да је у Италији богата југословенска књижевност, а на поезију се то посебно односи, недовољно позната и присутна. Сврха збирке, како је скромно дефинише аутор,

${ }^{1}$ О Рамоусу подробније уп. Мациери 2009. 
јесте да читаоцу понуди увид у разноврсну југословенску песничку продукцију и стога представља око педесетак најрепрезентативнијих имена. Пошто изричито избегава да вреднује или привилегује нека имена науштрб других, аутор се опредељује за хронолшку сукцесивност, према годинама рођења. Српски песници су бројни и добро заступљени и стога не чуди податак да је међу њима и Црњански представљен кратким медаљоном у уводном делу. Ту су садржани основни биографски подаци и Рамоус о његовом „рафинираном” поетском изразу закључује да као „истанчани уметник речи [...] који уме да подари својим стиховима нежни музички призвук” (Рамоус 1959: 50), осцилира између класичног модела и модернизма. Највероватније као пример због тога одабира Суматру (с. 50) и још три песме: Бајка (Fiaba), Cеренада (Serenata) и Траг (Traccia) у свом преводу (Рамоус 1959: 49-51).

Дакле, у обе антологије приређивачи стављају акценат на југословенски простор као заједнички именитељ поетских струја и тенденција и ово је важан моменат. С једне стране, Салвинијева антологија значи отварање према суседној књижевности у години оптерећеној ратним догађајима, док Рамоусова збирка треба да послужи као мост који доприноси раскрављивању напетих и политичким догађајима оптерећених односа између Италије и социјалистичке Југославије у послератном периоду, ако се има у виду и специфичност италијанског становништва у Истри.

Ту нову фазу са све интензивнијим односима између две суседне земље 60-тих година консолидује антологија једног од оснивача италијанске славистике и првог редовног професора српскохрватског језика и књижевности на Универзитету у Падови, Артура Кроније (Arturo Cronia, 1896-1967). Готово поетички наслов са лирском нијансом указује на субјективни избор: Најлепше странище српско-хрватске књижевности (Le pagine più belle della letteratura serbo-croata, 1963) а Кронија као уредник и преводилац експлицитно и потврђује да се при састављању водио сопственом лектиром и субјективном интуицијом. Образлажући своје ставове о преводилачком поступку, сматра да је сваки оригинал, а нарочито поетско дело, извор великих дилема са којима се суочава преводилац, сажетих у биному tradurre-tradire, према ком је превод изневеравање оригинала. Поткрепљује ову тезу Гетеовим концептом непреводљивости (Unübersetzlichkeit) и закључује да се оригинал може само „верно” репродуковати „поновним, новим исказивањем” оригинала (Кронија 1963: 9), што значи да је превод ново књижевно дело. У медаљону који претходи преводима стихова Поздрав (Saluto) и Суматра (Кронија 1963: 294) као и неколико пасуса из путописа Љубав у Тоскани (Кронија 1963: 295), Црњански и његово дело лоцирани су међу поетичке „изме” и слично ранијим исказима, акценат је на романтичним нотама српског песника који се пун пркоса и меланхолије препушта , [...] лутањима и суматраизмима по расцвалим стазама усиљених виртуозизама" (Кронија 1963: 293). Кронија је свестан песничких вредности опуса Милоша Црњанског, не пропушта ипак прилику да упути критичку жаоку на рачун модерних тенденција, откривајући на овај начин и своју недовољну еластичност, сензибилност и крутост као књижевног историчара и критичара. 
После ове антологије следи застој и нови преводи Црњанског се јављају тек три деценије касније, деведесетих година када Софија Зани (Sofia Zani) професор српско-хрватске књижевности на Универзитету у Падови, 1992. године објављује студију Цртице уз неке пасусе Милоша Црњанског (Chiose a certi passi di Miloš Crnjanski), у чијој је основи филозофско понирање у књижевни опус нашег аутора. Полазиште је анализа суматраистичких елемената у трилогији коју чине Суматра, Објашњење Суматре и Дневник о Чарнојевићу. Занијева се не зауставља на романтичарским и бунтовничким цртама које су подвлачили италијански слависти старије генерације, пре свега Кронија. По њој, Црњански је аутентичан и самосвојан песник и представља синтезу модернистичких токова (Зани 1992: 19). Ауторка илуструје ову тврдњу оригиналом Суматре и паралелним преводом који треба да дочара хармонију овог „ремек-дела” (Зани 1992: 11-12).

Исте 1992. г. код миланског издавача Аделфи (Adelphi) излази превод $\mathrm{Ce}$ оба, док ће Другу књигу сеоба Аделфи објавити 1998. У оба случаја преводилац је Лионело Костантини (Lionello Costantini, 1934-1994) са римског Универзитета Сапијенца, одличан познавалац нашег језика, врстан филолог и преводилац на италијански². Оба романа наишла су на велики одјек у културним рубрикама најважнијих италијанских дневних листова и специјализованих часописа („La Stampa”, „Corriere della Sera”, „La Repubblica”, „L'Indice dei Libri del Mese”, „La Rivista dei libri”)². Ради се готово у потпуности о негативно обојеним чланцима у којима су романи Црњанског полазиште за критику југословенске, тј. српске политике 90-тих година са тежиштем на ратовима и питању Косова.

У великом броју рецензија, приказа и анализа књижевно дело остало је у сенци, а изостало је вредновање романа: иконографски оквир, фотографије писца и његове супруге Виде, слика сеобе Срба Паје Јовановића, Дубровника, разрушених градова и мостова, без неопходних објашњења тенденциозно контекстуализују српског писца и роман Сеобе (Бањанин 2004: 516-519). Овај пример показује да је ишчитавање једног писца или дела често условљено ванкњижевним факторима који га представљају у позитивном или негативном светлу. У овом случају потписници текстова и рецензија су италијански новинари у културним рубрикама који су иначе врло добро обавештени и компетентни ${ }^{4}$. С друге стране, сарадници у часописима су најчешће универзитетски наставници разних профила (германисти, италијанисти), такође поуздани као истраживачи. Па ипак, 90-тих година сви они били су под утицајем политичке пресије и негативног тренда према Југославији и Србији, а то се одразило и на формирање предрасуда о писцу као што је Црњански и његово дело.

\footnotetext{
${ }^{2}$ Костантини је превео на италијански бројне писце, као што су Иво Андрић, Данило Киш, Меша Селимовић, Александар Тишма, Антоније Исаковић, Анте Ковачић, Ранко Маринковић, Предраг Матвејевић и др.

3 Уп. Баудино 1992: 19; Де Анђелис 1999: 34-36; Мари 1999: 35; Растело 1998: 27; Реалис Лук 1992: 21; Румиц 1999: 13; Вале 1999: 11.

4 УП. ноту 3.
} 
Објављивање Сеоба прати и занимљива полемика на страницама торинског дневног листа „La Stampa” (Баудино 1992: 19) везана за превод који је издавач Аделфи најпре поверио Љиљани Авировић, тада наставнику на Високој школи за тумаче и преводиоце Универзитета у Трсту, која се интензивно бавила и бави се још увек превођењем хрватских и српских писаца на италијански. Она радикално оспорава Костантинијев превод, а аргумент је да је ауторова проза „изневерена”, да је писац „лиофилизован”, да је роман изгубио у лепоти и најављује објављивање свог превода који је милански издавач одбио да штампа. У истом чланку оглашава се и Костантини који јавно узима на себе „одговорност” за свој превод и објашњава свој преводилачки credo, инсистирајући на ,дубокој” а не само привидној верности тексту. Ова отворена полемика у границама научног аргументовања потврђује не само изузетност романа него и компетентност ових италијанских преводилаца. Љиљана Авировић вратила се анализи и интерпретацији превода Сеоба са примерима у једном свом тексту о проблемима превођења књижевних дела са словенских језика на италијански (Авировић 1997: 345-347).

У новом миленијуму, током две протекле деценије, појавили су се нови преводи из песничког и прозног опуса Црњанског. У амбициозно и панорамски осмишљеној антологији Српска поезија двадесетог века (La poesia serba del Novecento, 2005) са преко тридесет заступљених имена песника, чија је главна уредница тадашњи професор наше књижевности и језика на Универзитету у Барију, Светлана Стипчевић (1940-2008). Она се у уводу критички осврће на недопустиву мањкавост адекватних антологијских и дидактичких приручника када се ради о србистици и управо то наводи као главни циљ антологије. Црњански је овде сажетим медаљоном представљен као изузетно важан авангардни иноватор модерног поетског израза са неколико превода: Суматру, Стражилово, Ламент над Београдом превео је Драган Мраовић, а Причу, Траг и Живот Рајна Мандолфо Живковић (Стипчевић, Ђанкане 2005: 65-85). И поред најбољих приређивачких интенција резултат је изостао, највећим делом због мањкавости превода који нису на нивоу италијанског песничког регистра (Бањанин 2016: 244-246). Антологија није задовољила критеријуме који се постављају озбиљним издањима ове врсте, те је највећим делом због тога данас готово непозната и не користи се у универзитетској настави.

Суматра се јавља у још једној песничкој антологији, тематски посвећеној Првом светском рату (La guerra d'Europa 1914-1918 raccontata dai poeti) која је публикована 2014. г., а приређивачи нису слависти, што је и разлика у односу на остале антологије. И поред тога што се ради о познатом и афирмисаном римском издавачу (Nottetempo), издање је мањкаво и са много пропуста, бар када се ради о Црњанском. Наиме, у садржају стоји назив стихова Србије (Serbia), док се заправо, на страницама посвећеним нашем песнику, нуди читаоцу оригинал и превод Суматре (2016: 196-197), али без икакве информације о преводиоцу. Ње нема ни у концизној белешци о нашем песнику (2016: 257), тако да с правом може да се констатује да издавачки подухват ни у овом случају није ни адекватно а ни озбиљно реализован. 
С друге стране, да је песнички опус Милоша Црњанског представљао константан изазов преводиоцима и приређивачима, показује и пример поеме Ламент над Београдом који на италијанском постоји у три верзије и са три различита наслова. У антологији С. Стипчевић и Д. Ђанкане из 2001, поему насловљену Il lamento di Belgrado потписује Драган Мраовић. Већ сам наслов је проблематичан јер посесивни генитивни предлог у овом случају није коректан и превод наслова је, дакле, погрешан. Утисак је да се ради о ламенту града Београда, а слични пропусти, непрецизности, неоправдане хиперинтервенције су бројне и мада циљ овог рада није вредновање превода које остављамо за неку другу прилику, ово је пример који потврђује да Мраовић, иако искусан преводилац са италијанског, није дорастао задатку ког се прихватио. Други превод Ламента објавио је у лепом двојезичном издању, са оригиналом и преводом паралелно, један мали издавач из Ровига 2010. г. Ради се о књижици невеликог обима, веома укусно опремљеној што се види по корицама и хартији. Аутор поетски рафинираног и префињеног превода насловљеног Lamento per Belgrado са уводом и пропратним објашњењима на крају је италијаниста Масимо Рицанте (Massimo Rizzante), а Божидар Станишић је потписник закључног текста о свом доживљају Црњанског (Црњански 2010). Овај превод ни мало не заостаје од Ламента у верзији слависткиње и филолога Розане Морабито (Rosanna Morabito) објављеног 2019. г. у часопису специјализованом за поезију, интерпретацију и превођење „Semicerchio. Rivista di poesia comparata", који издаје Универзитет у Сијени. Наслов текста је Поеме припадности Милоша Црьанског (I poemi dell'appartenenza di Miloš Crnjanski): у концизном уводу ауторка подвлачи да се ради о избору према субјективном нахођењу, а да се при превођењу руководила филолошким начелима, што значи подробном текстуалном анализом која претходи преводима и максималном прецизношћу (Морабито 2019: 43-60). Паралелно са оригиналом следе и преводи поема Стражилово, Сербиа, Ламент над Београдом којима спекуларно у некој врсти апендикса/додатка одговарају три кратке поетске целине Молитва (Preghiera), Суматра и Привиђења (Visioni). Морабито се у својој верзији опредељује за дословни италијански еквивалент предлога „над”, те је наслов Lamento sopra Belgrado. И поред тога што звучи неуобичајено, решење је прихватљиво, ако се узме у обзир да ce именица „lamento” везује и за средњовековни жанр који је у италијанској поезији био коришћен у стиховима народних тужбалица из 13. и 14. века али и у сликарству5. Морабито као искусан филолог предлаже књижевну опцију са симболичном позадином, за разлику од можда неутралнијег али такође адекватног и прихватљивог ,рег” из Рицантијеве верзије. Овај као и сви остали преводи Розане Морабито беспрекорни су, те могу да послуже као добар пример не само одличног познавања оба језика и њихових финеса, него су и одраз професионалности па и сензибилитета без којих је незамислив сваки, а посебно песнички превод.

\footnotetext{
${ }^{5}$ Упућујемо и на венецијанског сликара и бакроресца тзв. Падованске школе Андреа Мантења (Andrea Mantegna, 1431-1506) и на његову чувену слику у чијем наслову се јавња исти предлог ("Lamento sul Cristo morto").
} 
Година 2019. може да се сматра изузетно плодном јер поред ових превода излазе из штампе и два романа: код престижног издавача Мимезис (Mimesis) у едицији eLit, чији је уредник Масимо Рицанте (преводилац Ламента на италијански), као 19. књига излази из штампе Роман о Лондону (Romanzo di Londra) у преводу слависткиње и сербо-кроатисте Александре Андолфо (Alessandra Andolfo), а код римског издавача Elliot Дневник о Чарнојевићy (Diario di un reduce), који је приредио и превео слависта и филолог са римске Сапијенце Лука Ваљо (Luca Vaglio). Сем што се ради о изузетним догађајима, с обзиром на то да преводи српске књижевности нису фреквентни последњих деценија, на овај начин, заокружен је опус Милоша Црњанског. Није занемарујућа чињеница да су оба преводиоца слависти специјализовани и за српски језик и књижевност, што се одражава чак и на форму: оба превода су обогаћена критичким апаратом који контекстуализује роман, белешкама и фуснотама или нотама на крају текста. Андолфо у уводној белешци указује (Nota del traduttore) комплексност целокупног романескног опуса која се рефлектује не само на тематском нивоу, него и у структуралном због фреквентних прелаза са прошлог/прошлих времена на презент чија је функција разноврсна, али преко ње се открива и сложена психолошка структура ликова. Као преводилац Андолфо запажа да управо алтернација глаголских времена која код српских говорника не представља проблем, у процесу превођења постаје замка јер структура италијанског језика захтева поштовање правила сукцесивности, те је то потешкоћа која ставља преводиоца пред друге одлуке. Овоме треба додати и згуснутост текста коју обележава посебна и често необична интерпункција коју Андолфо задржава сем у случајевима где би превод италијанском читаоцу био неразумљив (Црњански 2019а: 5-6). Преко осам стотина страна овог италијанског превода још један су омаж Милошу Црњанском, као и превод Дневника о Чарнојевићу, који је приредио и превео Лука Ваљо. Овом преводу претходи и онај под насловом Il diario di Čarnojević, који је изашао у Швајцарској, у Лугану 2014. године, али тај превод није имао великог одјека и готово је непознат, што је можда последица недовољне ажурности издавача у промоцији књиге (Црњански 2014). Преводилац је Милица Бабић, изворни говорник и највероватније је то узрок мањкавости превода за који може да се претпостави да није био подвргнут ригорозној лектури коју већина издавача данас не практикује. Неколико страница из Дневника објављено је и у књизи коју је деценију раније приредила Марија Митровић Sul mare brillavano vasti silenzi (2004). Она је ауторка уводног медаљона о Црњанском и његовом опусу, а Аличе Пармеђани (Alice Parmeggiani) је преводилац неколико страница, а наслов је Meтorie su Čarnojević (Митровић 2004: 129-130, 131-134). У верзији Луке Ваљо роман је насловљен Diario di un reduce (Дневник једног повратника) (Црњански 2019б), што би могло да се протумачи као удаљавање од оригинала, да преводилац истовремено и приређивач, није додао уводни текст са прецизном и обухватном биографском, историјском и литерарном контекстуализацијом аутора, његовог целокупног опуса и романа. Овај наслов преводилац сматра адекватнијим и због тога што су експресионистички аутори практиковали да 
дају наслове својим делима који нису директно везани за сам текст. Због тога и Дневник у оригиналу носи име Чарнојевића, који је наизглед секундарни лик, мада је његова функција у наративној равни изузетна јер представља суматраистички симбол. Ваљо не спомиње експлицитно претходни превод, али подвлачи да је наслов за који каже да се најчешће налази у италијанском, Diario di Čarnojević, заправо погрешан јер би он требало да гласи Diario su Čarnojević. Тај уобичајени наслов Ваљо сматра „веома незграпним”, „естетски дефицитарним” ("oltremodo sgraziato”, „esteticamente deficitario”) (Црњански 2019б: 17). Ово су разлози због којих он сматра адекватнијим свој предлог са модификованим другим делом у коме се „повратник” уклапа у текст. Већ ово указује на то да је преводилац са много компетентности приступио реализацији подухвата, те је и превод као резултат добар, чита се лако у течном и мелодичном италијанском са пуно нијанси које филолог осећа. Богат критички апарат са фуснотама даје додатна објашњења неопходна италијанском читаоцу, без којих би роман Милоша Црњанског био непрозиран. Занимљиво је да Ваљо даје и свој превод Суматре. Ни он, као ни Морабито не позива се на претходне преводе. Ваљо сматра да Суматра представља мост ка прозном опусу и због тога даје свој предлог превода.

У закључку, а како би се стекао увид у опус Милоша Црњанског на италијанском који читалац има на располагању, треба додати и неколико бројчаних података: најпревођенија је Суматра са 8 верзија у периоду од 80 година (Салвини, Рамоус, Кронија, Зани, Мраовић, аноним, Морабито, Ваљо). Следи Ламент над Београдом са 3 превода (Мраовић, Рицанте, Морабито), Траг са по 2 (Рамоус, Мандолфо Живковић) као и Стражилово (Мраовић, Морабито). У једној верзији су доступни: Бајка и Серенада (Рамоус), Поздрав (Кронија), Прича и Живот (Мандолфо Живковић), Молитва и Привиђења (Морабито). Када се ради о романима, Сеобе и Другу књигу Сеоба превео је Костантини, Роман о Лондону Андолфо, Дневник о Чарнојевићу Бабић и Ваљо.

Дакле, можемо да констатујемо да је Црњански поред Иве Андрића један од најпревођенијих наших писаца. Његов песнички и прозни опус у преводима је компактан, захваљујући пре свега ангажовању италијанских слависта који су последњих година заокружили и проширили увид у Црњанског као завичајног песника, једног од најважнијих модерниста и представника српског романа 20. века (Бањанин 2019). Преводилац није песник и за разлику од њега, нема апсолутну слободу, његов инвентар припада језику, у нашем случају генетски, структурално и функционално другачијем од српског. Због тога је он често принуђен на компромисе и жртве и стога је фундаментално добро познавање полазног и циљног језика, свих његових аспеката, миљеа у коме је дело настало као и поетски сензибилитет који није привилеговани дар чак ни изворних говорника. Превод је рефлекс и одраз оригинала, резултат преводиочевог читања, интерпретације и најчешће као што смо видели, субјективних критеријума и личног сензибилитета. Превођење на италијански Црњанског био је и јесте велики изазов и разне варијанте истог дела то потврђују: са његовим стиховима а и прозом носили су се слависти, ита- 
лијанисти, преводиоци, песници. Резултат је изостао тамо где аутор превода није на висини задатка, док су равни лепоти оригинала они преводи чији су потписници слависти.

Питање превођења намеће се и остаје једно од највиталнијих у рецепцији и циркулацији књижевних дела. Не постоји идеалан превод, али ни правило ког преводилац може/треба/мора да се придржава, кодификација из једног језика у други подразумева алтерацију значења, у неким случајевима и дисперзију поруке. Ако је задатак преводиоца да у новом језику реализује специфичност оригинала, али и да сачува особени смисао његове поруке, он је могућ само дубоким понирањем у текст и његове меандре, а већина италијанских преводилаца је то и постигла.

\section{ЛИТЕРАТУРА}

Авировић 1996: Lj. Avirović, „Migrazioni” di Miloš Crnjanski: una revisione critica della traduzione, RITT-Rivista internazionale di tecnica della traduzione, n. 2, Università degli Studi di Trieste/SSLM, 54-60.

Авировић 1997: Lj. Avirović, Ibrido o equivalenze: sulla traduzione letteraria in italiano dalle lingue slave, in Tradurre. Un approccio multidisciplinare, a cura di Margherita Ulrych, Torino: UTET, 345-347.

Америо, Паче Отиери 2014: A. Amerio, M. Pace Ottieri, a cura di, La guerra d'Europa 1914-1918 raccontata dai poeti, Roma: Nottetempo.

Бањанин 2004: Љ. Бањанин, Милош Црњански у италијанској научно-популарној литератури, Научни састанак слависта у Вукове дане. Књижевно дело Милоша Црњанског и поетичке промене у савременој српској књижевности, 33/2, Београд: МСЦ, 509-520.

Бањанин 2016: Lj. Banjanin, Italijanski prevodi Sumatre Miloša Crnjanskog, Kulture u prevodu. Tematski zbornik, 1, prir. A. Vraneš, Lj. Marković, Beograd: Filološki fakultet, 231-248.

Бањанин 2019: Lj. Banjanin, La vocazione alla solitudine, L'Indice dei Libri del mese, XXXVI, 12, 19.

Баудино 1992: M. Baudino, Serbi, la saga dei guerrieri tristi, La Stampa, a. 126, n. $186,9.7 .1992,19$.

Вале 1999: R. Valle, Mosche senza testa. Sangue, nostalgia e destino nel mito del Kosovo e nell'epos nazionale dei serbi, L'Indice dei Libri del Mese, XVI, 5, 11.

Де Анђелис 1999: E. De Angelis, La Grande Serbia, La Rivista dei Libri, IX, 7-8, 34-36.

Зани 1992: S. Zani, Chiose a certi passi di Miloš Crnjanski. Padova: Istituto di Filologia Slava, Università di Padova.

Кронија 1963: A. Cronia, Le più belle pagine della letteratura serbo-croata. Milano: Nuova Accademia. 
Мари 1999: M. Marri, La vera patria è altrove. Le migrazioni serbe verso la Russia descritte da Crnjanski con qualche leziosità, Corriere della Sera, 124, 68, 21. 3. 1999, 35.

Мациери 2009: G. Mazzieri, Osvaldo Ramous. Il giornalismo, l'impegno culturale e critico, Fiume: EDIT.

Митровић 2004: М. Mitrović, Sul mare brillavano vasti silenzi. Immagini di trieste nella letteratura serba, Trieste: Il Ramo d'Oro.

Морабито 2019: R. Morabito, I poemi dell'appartenenza di Miloš Crnjanski, Semicerchio. Rivista di poesia comparata, LX/2, 43-60.

Рамоус 1959: O. Ramous, Poesia jugoslava contemporanea: prima traduzione in lingua italiana, Padova: Rebellato Ed.

Растело 1998: L. Rastello, Miloš Crnjanski. Migrazioni I, L’Indice dei Libri del Mese, IX, 11, 27.

Реалис Лук 1992: O. Realis Luc, Guerra e passione sotto la pioggia, L'Indice dei Libri del Mese, IX, 11, 21.

Румиц 1999: P. Rumiz, Nel mattatoio delle memorie, La Repubblica, XXIV, 75, 31. 3. $1999,13$.

Салвини [1942]: L. Salvini, Le candide Vile. Poesie Jugoslave. Roma: Edizioni della Cometa.

Стипчевић,Ђанкане 2005: S. Stipcevic, D. Giancane (a cura di). La poesia serba del Novecento. Bari: Levante Editori.

Црњански 1965: М. Црњански, Лирика. Проза. Есеји, Нови Сад, Београд: Матица српска, Српска књижевна задруга.

Црњански 2010: M. Crnjanski, Lamento per Belgrado. Prefazione di M. Rizzante con uno scritto di B. Stanišić, trad. a cura di M. Rizzante. Testo serbo a fronte, Rovigo: Il Ponte del Sale.

Црњански 2014: M. Crnjanski, Il diario di Čarnojević, trad. M. Babić, Lugano: ADV Advertising Company.

Црњански 2019a: M. Crnjanski, Romanzo di Londra, trad. A. Andolfo, con una postfazione di B. Stanišić, Milano-Udine: Mimesis.

Црњански 2019б: M. Crnjanski, Diario di un reduce, trad. e cura di L. Vaglio, Roma: Eliot. 


\section{Ljiljana M. Banjanin}

FROM SUMATRA TO DNEVNIK O ČARNOJEVIĆU: ITALIAN TRANSLATIONS OF CRNJANSKI'S WORKS INTO ITALIAN

\section{Summary}

The main idea of the paper focuses on the translations of poetical and prose works of Miloš Crnjanski into Italian, starting with Sumatra and Lament nad Beogradom, to the novels Seobe, Roman $o$ Londonu and Dnevnik o Čarnojeviću. The aim is to identify the problems related to the translation of poetry and literary works in general, as well as the role of the translator. To a great extent, the result of the process, i.e. good/bad translation, depends on the professional profile and the agility of the translator. This consequently affects the way in which literary works and authors are received in a foreign environment, in our case in Italian. 